\title{
Diploid potatoes as a source of high resistance to bacteria Pectobacterium atrosepticum
}

\author{
Ziemniaki diploidalne źródłem wysokiej odporności \\ na bakterie Pectobacterium atrosepticum
}

\author{
Renata Lebecka, Henryka Jakuczun, Iwona Wasilewicz-Flis, Ewa Zimnoch-Guzowska
}

\begin{abstract}
Summary
Blackleg and soft rot are two diseases of potato caused by pectinolytic bacteria of genus Pectobacterium and Dickeya. In Poland major bacteria causing these diseases are Pectobacterium atrosepticum $(\mathrm{Pa})$ and Pectobacterium carotovorum subsp. carotovorum. Potato resistance to bacteria $\mathrm{Pa}$ is a polygenically inherited trait. All potato cultivars are susceptible to these bacteria, but they differ in the level of susceptibility. From 2006 to 2011394 diploid potato clones were tested for resistance to Pa. These clones have in their origin, beside Solanum tuberosum, a range of wild and primitive cultivated potato species. The resistance was evaluated in 1-9 scale, where 9 is the most resistant. In two and three-year evaluation seven diploid clones of potato have been scored 7.0. It was the highest resistance among all tested clones. The most resistant potato cultivars Gandawa, Ślęza and Glada, were scored: 5.0, 5.0 and 4.9 respectively. The most susceptible cultivar Irys was scored 2.7. Diploid potato hybrids can be used in breeding and research on the resistance to soft rot.
\end{abstract}

Key words: potato, diploid hybrids breeding, soft rot, resistance, Pectobacterium atrosepticum

\section{Streszczenie}

Czarna nóżka ziemniaka i mokra zgnilizna bulw ziemniaka to dwie choroby wywoływane przez pektynolityczne bakterie z rodzajów Pectobacterium i Dickeya. W Polsce głównymi sprawcami tych chorób są bakterie Pectobacterium atrosepticum (Pa) i P. carotovorum subsp. carotovorum. Odporność ziemniaka na Pa jest warunkowana poligenicznie. Wszystkie odmiany są podatne na te bakterie, ale różnią się poziomem podatności. W latach 2006-2011 przetestowano pod względem odporności na Pa 394 diploidalne klony ziemniaka, które w swoim pochodzeniu, oprócz Solanum tuberosum, posiadają szereg dzikich i prymitywnie uprawnych gatunków Solanum. Odporność oceniano w skali od 1-9, gdzie 9 oznacza najodporniejszy. W badaniach dwuletnich i trzyletnich wyselekcjonowano siedem klonów diploidalnych ziemniaka odpornych na mokrą zgniliznę bulw ziemniaka w stopniu 7,0. Jest to najwyższa odporność na Pa wśród wszystkich badanych klonów. Najwyżej ocenione odmiany ziemniaka - Gandawa, Ślęza i Glada otrzymały średnie oceny: 5,0; 5,0 i 4,9. Najpodatniejszą odmianą w badaniach była odmiana Irys, oceniona średnio na 2,7. Mieszańce diploidalne ziemniaka mogą być wykorzystane w hodowli do uzyskania odmian z odpornością na mokrą zgniliznę bulw ziemniaka oraz do celów badawczych.

Słowa kluczowe: ziemniak, diploidalny ziemniak, hodowla, mokra zgnilizna bulw ziemniaka, odporność, Pectobacterium atrosepticum

Instytut Hodowli i Aklimatyzacji Roślin - Państwowy Instytut Badawczy

Platanowa 19, 05-831 Młochów

r.lebecka@ihar.edu.pl 


\section{Wstęp / Introduction}

Czarna nóżka ziemniaka i mokra zgnilizna bulw ziemniaka to choroby powodowane przez bakterie $\mathrm{z}$ rodzajów Pectobacterium i Dickeya (Gardan i wsp. 2003), które dzięki zdolności wytwarzania enzymów pektynolitycznych powodują rozkład blaszek środkowych - substancji pektynowych spajających komórki roślinne. W Polsce głównymi sprawcami mokrej zgnilizny bulw ziemniaka sa bakterie Pectobacterium atrosepticum $(\mathrm{Pa})$ i $P$. carotovorum subsp. carotovorum (Pcc). Udział bakterii Dickeya w rozwoju tych chorób wykryto w Polsce niedawno (Sławiak i wsp. 2009). Bakterie przedostają się do bulw ziemniaka przez zranienia oraz przetchlinki i przez cały okres przechowywania moga pozostawać w nich w formie latentnej, nie wywołując objawów choroby. W pewnych warunkach, jak np. ograniczony dostęp tlenu i/lub podwyższona temperatura, bakterie mogą zacząć produkować enzymy pektynolityczne i wywoływać gnicie bulw. Bulwy $\mathrm{z}$ bakteriami $\mathrm{W}$ formie utajonej posadzone $\mathrm{W}$ polu, w sprzyjających warunkach są źródłem zakażenia dla bulw potomnych, na roślinach, które $\mathrm{z}$ nich wyrosły, może rozwinąć się czarna nóżka ziemniaka (Perombelon i Kelman 1980). Nie stosuje się ochrony chemicznej ziemniaka przeciw mokrej zgniliźnie bulw ziemniaka i czarnej nóżce ziemniaka. Większość składników środków ochrony zawiera antybiotyki, które nie sa dozwolone do stosowania na szeroką skalę ze względu na ryzyko uodpornienia się bakterii patogenicznych dla ludzi i zwierząt (Czajkowski i wsp. 2011). Odporność bulw ziemniaka na bakterie pektynolityczne ma charakter poligeniczny (ZimnochGuzowska wsp. 2000; Lebecka i Zimnoch-Guzowska 2004; Lebecka i wsp. 2004). W warunkach optymalnych dla rozwoju bakterii w ziemniaku nie występuje odporność całkowita. Odporność bulw na te bakterie jest relatywna i zależy od różnych czynników, z których najważniejsze to wirulencja bakterii, dostęp tlenu i temperatura (Perombelon 2002). Poziom odporności odmian ziemniaka na bakterie Pa jest średni lub niski. Podwyższoną odporność na mokrą zgniliznę bulw ziemniaka z Solanum commersonii wprowadzono do form trzeciego pokolenia krzyżowań wstecznych (BC3) z S. tuberosum (Carputo i wsp. 2002). Wysoka odporność na Pcc została również przeniesiona do ziemniaka uprawnego $\mathrm{z}$ diploidalnego klonu S. brevidens na drodze fuzji somatycznej, a następnie $w$ trzech krzyżowaniach wstecznych $\mathrm{z}$ odmianami ziemniaka (Tek i wsp. 2004). Do tej pory nie otrzymano odmiany ziemniaka o wysokiej odporności na mokrą zgniliznę bulw pochodzącej od wysokoodpornych dzikich gatunków ziemniaka.

Celem pracy jest przedstawienie poziomu odporności na Pa klonów diploidalnych ziemniaka otrzymanych w Instytucie Hodowli i Aklimatyzacji Roślin - Państwowego Instytutu Badawczego w Młochowie (IHAR - PIB) jako potencjalnego źródła tej cechy w tworzeniu tetraploidalnych form o wyższej odporności na te bakterie w stosunku do najwyższej możliwej, czyli średniej odporności odmian.

\section{Materiały i metody / Materials and methods}

\section{Materiał roślinny}

Materiałem były 394 złożone mieszańce międzygatunkowe ziemniaka diploidalnego, wyselekcjonowane w Pracowni Genetyki w IHAR - PIB, Oddział Młochów. Klony te posiadaja w swoim pochodzeniu oprócz $S$. tuberosum od kilku do dziesięciu dzikich i prymitywnie uprawnych gatunków Solanum: S. acaule, S. andigena, S. chacoense, $S$. demissum, $S$. goniocalyx, $S$. gourlayi, S. microdontum, S. phureja, S. stenotomum, S. stoloniferum, S. tuberosum, S. verrucosum, S. yungasense. Jako standardy oceniano cztery odmiany ziemniaka: Glada, Gandawa, Ślęza i Irys, o różnym poziomie odporności na mokrą zgniliznę.

\section{Izolaty bakterii}

Zastosowano izolaty $P$. atrosepticum $(\mathrm{Pa}) \mathrm{z}$ kolekcji własnej ( $\mathrm{Pa} 4 / 06, \mathrm{~Pa} 2 / 06$ - w trzech latach badań) oraz izolat 56A/4/2005/20 (Pa) otrzymany od prof. E. Łojkowskiej z Międzyuczelnianego Wydziału Biotechnologii Uniwersytetu Gdańskiego i Gdańskiego Uniwersytetu Medycznego w Gdańsku. Izolaty wybierano na podstawie wyników testu wirulencji, przeprowadzanego przed oceną odporności w każdym roku badań.

\section{Inokulacja i ocena odporności}

Testy przeprowadzono w latach 2006-2011 (w 2009 r. nie wykonywano testu). Wyniki obejmują badania jednoroczne (dotyczące form o wysokiej podatności) oraz dwuletnie - do pięcioletnich. Odporność bulw ziemniaka na $\mathrm{Pa}$ oceniano stosując metodę punktowej inokulacji bulw (Lebecka 2001). Bulwy nakłuwano w dwóch miejscach za pomocą tępo zakończonego bolca o długości $1 \mathrm{~cm}$ i średnicy $2 \mathrm{~mm}$. W każde nakłucie wprowadzano końcówkę mikropipety zawierająca $80 \mu$ zawiesiny bakterii Pa o koncentracji $5 \times 10^{8}$ jednostek tworzących kolonie w $1 \mathrm{ml}$ (rys. 1a). Inokulowane bulwy układano na wyłożonej mokrą ligniną kuwecie, zraszano po inokulacji wodą i przykrywano szybą. Inkubacja bakterii odbywała się w ciemności, w temperaturze $20^{\circ} \mathrm{C}$. Po 6 dniach mierzono porażenie na przekroju bulw wzdłuż miejsca inokulacji (rys. 1b, c). Porażenie wyrażano jako średnią średnicy plamy gnilnej $\mathrm{w} \mathrm{mm}$. Wyniki $\mathrm{w} \mathrm{mm}$ transformowano na tradycyjną skalę 1-9, gdzie 9 - oznacza najodporniejszy (Ratuszniak i wsp. 1978). Skalę porażenia przedstawiono w tabeli 1.

\section{Wyniki i dyskusja / Results and discussion}

Odporność klonów diploidalnych ziemniaka na Pa jest jedną z wielu cech ocenianych w IHAR - PIB w Młochowie, w procesie ich selekcji (Zimnoch-Guzowska i wsp. 1999). W tabeli 1. przedstawiono wyniki oceny odporności klonów diploidalnych i odmian ziemniaka testowanych w jednym roku do pięciu lat. Wyniki jednoroczne pokazują zmienność badanej cechy w danym 
Tabela 1. Odporność 394 diploidalnych klonów i czterech odmian ziemniaka na bakterie P. atrosepticum

Table 1. Resistance of 394 diploid clones and four potato cultivars to bacteria P. atrosepticum

\begin{tabular}{|c|c|c|c|c|c|c|c|}
\hline \multirow[b]{3}{*}{$\begin{array}{l}\text { Odporność* } \\
\text { Resistance }\end{array}$} & \multirow{3}{*}{$\begin{array}{c}\text { Średnica porażenia } \\
\text { Diameter of rotten tissue } \\
{[\mathrm{mm}]}\end{array}$} & \multicolumn{6}{|c|}{ Liczba lat ocen - Number of testing years } \\
\hline & & 1 & 2 & 3 & 4 & 5 & \multirow{3}{*}{$\begin{array}{c}\text { suma - sum } \\
0\end{array}$} \\
\hline & & \multicolumn{5}{|c|}{$\begin{array}{l}\text { liczba diploidalnych klonów ziemniaka w klasach odporności, } \\
\text { odporność odmian (w nawiasach średnia } \pm \mathrm{SD} \text { ) } \\
\text { number of diploid clones of potato in resistance ranges, } \\
\text { resistance of potato cultivars (in brackets mean } \pm \mathrm{SD} \text { ) }\end{array}$} & \\
\hline 9 & $2,0-2,6$ & & & & & & \\
\hline $8-8,9$ & $2,7-4,6$ & & & & & & 0 \\
\hline $7-7,9$ & $4,7-7,7$ & 26 & 3 & 4 & & & 33 \\
\hline $6-6,9$ & $7,8-11,4$ & 77 & 13 & 13 & 7 & & 110 \\
\hline $5-5,9$ & $11,5-15,4$ & 94 & $\begin{array}{c}17 \\
\text { Ślęza } \\
(5,0 \pm 1,4)\end{array}$ & 4 & 2 & $\begin{array}{l}\text { Gandawa } \\
(5,0 \pm 1,0)\end{array}$ & 117 \\
\hline $4-4,9$ & $15,5-19,1$ & 82 & 8 & & & $\begin{array}{c}\text { Glada } \\
(4,9 \pm 0,3)\end{array}$ & 90 \\
\hline $3-3,9$ & $19,2-22,2$ & 26 & & & & & 26 \\
\hline $2-2,9$ & $22,3-24,2$ & 10 & & $\begin{array}{c}\text { Irys } \\
(2,7 \pm 1,5)\end{array}$ & & & 10 \\
\hline $1-1,9$ & $24,3-25,0$ & 8 & & & & & 8 \\
\hline Suma - Sum & & 323 & 41 & 21 & 9 & & 394 \\
\hline
\end{tabular}

*odporność w skali 1-9, gdzie 9 - najodporniejszy - resistance in scale 1-9, where 9 - the most resistant

Tabela 2. Udział gatunków Solanum w pochodzeniu odpornych klonów diploidalnych mieszańców ziemniaka Table 2. Share of Solanum species in the origin of resistant diploid potato hybrid clones and potato cultivars

\begin{tabular}{|c|c|c|c|c|c|c|c|c|c|}
\hline \multirow{2}{*}{$\begin{array}{l}\text { Gatunki Solanum } \\
\text { Solanum species }\end{array}$} & \multicolumn{7}{|c|}{ Diploidalne klony ziemniaka - Diploid potato clones } & \multicolumn{2}{|c|}{$\begin{array}{l}\text { Odmiany } \\
\text { Cultivars }\end{array}$} \\
\hline & DG00-269 & DG00-270 & DG00-349 & DG00-481 & DG07-154 & DG06-5 & DG06-6 & Irys & Glada \\
\hline S. acaule & & & & & + & + & + & & \\
\hline S. andigena & & & & & + & + & + & & + \\
\hline S. chacoense & + & + & + & + & + & + & + & & \\
\hline S. demissum & & & & & + & + & + & + & \\
\hline S. gourlayi & & & + & + & + & + & + & & \\
\hline S. microdontum & + & + & + & + & & & & & \\
\hline S. phureja & + & + & + & + & + & & & & \\
\hline S. stenotomum & & & & & + & & & & \\
\hline S. stoloniferum & & & & & + & + & + & & \\
\hline S. tuberosum & + & + & + & + & + & + & + & + & + \\
\hline S. verrucosum & + & + & + & + & & & & & \\
\hline S. yungasense & + & + & + & + & + & + & + & & \\
\hline
\end{tabular}

materiale. Zakres odporności na mokrą zgniliznę bulw ziemniaka był od 1,0 do 7,0. Klony ocenione jako podatne w pierwszym roku nie były testowane w kolejnych latach. W następnych latach testowano formy, które w pierwszym roku uzyskały ocenę przynajmniej 5,0. Z badanych 394 klonów diploidalnych, przez dwa lata testowano 41 klonów, przez trzy lata 21 i dziewięć klonów przez cztery lata (tab. 1). Najwyższym poziomem odporności (w stopniu $7,0)$ w badaniach dwu- i trzyletnich charakteryzowało się siedem klonów diploidalnych ziemniaka: DG00-270, DG00-349, DG00-481, DG06-5, DG00-269, DG06-6,
DG07-154. Są to złożone mieszańce międzygatunkowe ziemniaka, w których oprócz dominującego udziału S. tuberosum znajdują się różne dzikie i prymitywnie uprawne gatunki przedstawione w tabeli 2. Spośród nich następujące gatunki wymieniano jako źródła odporności bulw na bakterie z rodzaju Pectobacterium: $S$. acaule, S. chacoense, S. demissum, S. gourlayi, S. microdontum, S. phureja, S. stenotomum, S. tuberosum subsp. andigena, S. yungasense (Koromyslova 1972; Hidalgo i Echandi 1983; Łojkowska i Kelman 1989; Rousselle-Bourgeois 
i Priou 1995; Watanabe i Watanabe 2000; Lebecka i wsp. 2004).

W badaniach jednorocznych 26 klonów diploidalnych otrzymało ocenę 7,0. Ocenę od 6,0 do 6,9 otrzymały 33 klony w badaniach dwu- i trzyletnich oraz 77 klonów w pierwszym roku badań. Wskazuje to na duży potencjał klonów diploidalnych pod względem odporności na mokrą zgniliznę bulw ziemniaka $\mathrm{w}$ porównaniu do poziomu tej cechy w odmianach ziemniaka. Najbardziej odporne odmiany ziemniaka uzyskały ocenę 5,0 (odmiany Ślęza i Gandawa) i 4,9 (odmiana Glada). Najbardziej podatna była odmiana Irys, oceniona $\mathrm{w}$ badaniach trzyletnich na 2,7. Odmiany Glada i Irys służą w testach jako odmiany wzorcowe (rys. 1b, c), według reakcji których ocenia się odporność diploidalnych klonów ziemniaka. W „Charakterystyce Krajowego Rejestru Odmian Ziemniaka” (IHAR PIB, Jadwisin 2012) odporność na mokrą zgniliznę bulw ziemniaka odmian Glada i Irys została oceniona bardzo podobnie i wynosi odpowiednio 5,0 i 3,0. Nie ma odmiany o wyższej odporności od odporności odmiany Glada, a jej poziom reprezentują jeszcze cztery inne odmiany skrobiowe. Charakterystyka odporności na mokrą zgniliznę bulw ziemniaka dotyczy 28 odmian ze 136 znajdujących się w Krajowym Rejestrze Odmian Ziemniaka. Od pewnego czasu nowo rejestrowane odmiany nie są oceniane pod względem odporności na mokrą zgniliznę bulw ziemniaka. Warunki prowadzonych testów były korzystne dla rozwoju mokrej zgnilizny bulw ziemniaka. Można zatem oczekiwać, że formy wyselekcjonowane jako najodporniejsze w takich warunkach, nie ulegną gniciu w mniej sprzyjających warunkach dla rozwoju bakterii w warunkach naturalnych. Szereg klonów diploidalnych wytwarza męskie lub żeńskie gamety o niezredukowanej liczbie chromosomów (gamety $2 n$ ), dzięki którym allele odporności mogą być bezpośrednio przeniesione na poziom tetraploidalny w krzyżowaniach interploidalnych $4 x \times 2 x$ lub $2 x \times 4 x$ (Capo i wsp. 2002; Lebecka i wsp. 2004).

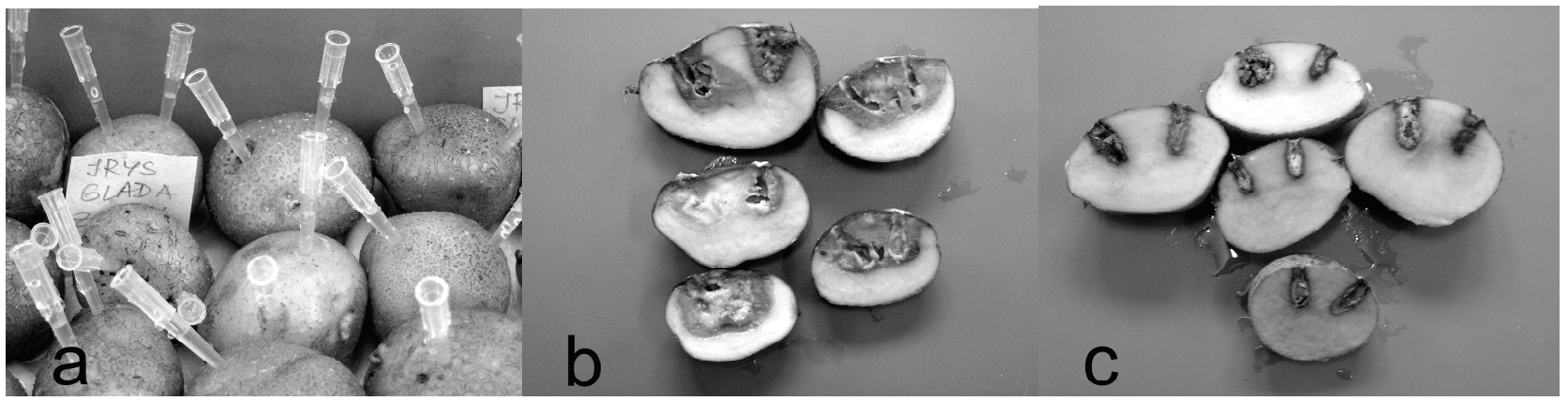

Rys. 1. (a) metoda punktowej inokulacji bulw, (b) objawy porażenia bulw odmiany Glada i (c) odmiany Irys przez bakterie $P$. atrosepticum (fot. Renata Lebecka)

Fig. 1. (a) point inoculation method, (b) symptoms of infection with bacteria, P. atrosepticum in tubers of cultivar Glada and (c) cultivar Irys (phot. Renata Lebecka)

\section{Wnioski / Conclusions}

1. Klony diploidalne ziemniaka są źródłem wysokiej odporności na bakterie $P$. atrosepticum wywołujące mokrą zgniliznę bulw ziemniaka i mogą być użyte jako formy rodzicielskie w programie hodowli na poziomie diploidalnym, a dzięki ich zdolności do tworzenia ga- met o niezredukowanej liczbie chromosomów również w programie hodowli na poziomie tetraploidalnym.

2. Podniesienie odporności na Pa w materiałach hodowlanych jest potrzebne i możliwe przez wykorzystanie odpornych klonów diploidalnych.

\section{Literatura / References}

Carputo D., Frusciante L., Monti L., Paris M., Barone A. 2002. Tuber quality and soft rot resistance of hybrids between Solanum tuberosum and the incongruent wild relative $S$. commersonii. Am. J. Potato Res. 79 (5): 345-352.

Capo A., Cammareri M., Della Rocca E., Errico A., Zoina A., Conicella C. 2002. Evaluation for chipping and tuber soft sot (Erwinia carotovora) resistance in potato clones from unilateral sexual polyploidization $(2 x \times 4 x)$. Am. J. Potato Res. 79 (2): $139-145$.

Charakterystyka Krajowego Rejestru Odmian Ziemniaka. 2012. Instytut Hodowli i Aklimatyzacji Roślin - Państwowy Instytut Badawczy, Oddział Jadwisin, wyd. XV, 40 ss.

Czajkowski R., Perombelon M.C.M., van Veen J.A., van der Wolf J.M. 2011. Control of blackleg and tuber soft rot of potato caused by Pectobacterium and Dickeya species: a review. Plant Pathol. 60 (6): 999-1013.

Gardan L., Couy C., Christen R., Galan J.E. 2003. Evaluation of three subspecies of Pectobacterium carotovorum to species level: Pectobacterium atrosepticum sp. nov., Pectobacterium betavasculorum sp. nov. and Pectobacterium wasabiae sp. nov. Int. J. Syst. Evol. Microbiol. 53 (2): 381-391. 
Hidalgo D.A., Echandi E. 1983. Influence of temperature and length of storage on resistance of potato to tuber rot induced by Erwinia chrysanthemi. Am. Potato J. 60 (1): 1-17.

Koromyslova M.I. 1972. Initial material for breeding potatoes for resistance to blackleg. Byull. Vesoyuznogo Ordena Lenina Inst. Rastenievodstva Imeni N. I. Vavilova 22: 35-38.

Lebecka R. 2001. Ocena odporności bulw na mokrą zgniliznę w teście bulwowym i plastrowym. Monografie i Rozprawy Naukowe IHAR Radzików 10: 83-85.

Lebecka R., Zimnoch-Guzowska E. 2004. The inheritance of resistance to soft rot (Erwinia carotovora subsp. atroseptica) in diploid potato families. Am. J. Potato Res. 81 (6): 395-401.

Lebecka R., Zimnoch-Guzowska E., Kaczmarek Z. 2004. Resistance to soft rot (Erwinia carotovora subsp. atroseptica) in tetraploid potato families obtained from $4 x-2 x$ crosses. Am. J. Potato Res. 82 (3): 203-210.

Łojkowska E., Kelman A. 1989. Screening of seedlings of wild Solanum species for resistance to bacterial stem rot caused by soft rot erwinias. Am. Potato J. 66 (6): 379-389.

Perombelon M.C.M. 2002. Potato diseases caused by soft rot erwinias: an overview of pathogenesis. Plant Pathol. 51 (1): 1-12.

Perombelon M.C.M., Kelman A. 1980. Ecology of the soft rot Erwinia. Annu. Rev. Phytopathol. 18: 361-387.

Ratuszniak E., Trętowski J., Mogielnicki A. 1978. Metodyka badania odporności materiałów hodowlanych ziemniaka na suchą zgniliznę bulw. Ziemniak: 39-54.

Rousselle-Bourgeois F., Priou S. 1995. Screening tuber-bearing Solanum spp. for resistance to soft rot caused by Erwinia carotovora ssp. atroseptica (van Hall). Potato Res. 38 (1): 111-118.

Sławiak M., Łojkowska E., van der Wolf J.M. 2009. First report of bacterial soft rot on potato caused by Dickeya sp. (syn. Erwinia chrysanthemi) in Poland. Plant Pathol. 58, p. 794.

Tek A.L., Stevenson W.R., Helgeson J.P., Jiang J. 2004. Transfer of tuber soft rot and early blight resistances from Solanum brevidens into cultivated potato. Theor. Appl. Genet. 109: 249-254.

Watanabe J.A., Watanabe K.N. 2000. Pest resistance traits controlled by quantitative loci and molecular breeding strategies in tuberbearing Solanum. Plant Biotech. 17 (1): 1-16.

Zimnoch-Guzowska E., Lebecka R., Pietrak J. 1999. Soft rot and blackleg reactions in diploid potato hybrids inoculated with Erwinia spp. Am. J. Potato Res. 76 (4): 199-207.

Zimnoch-Guzowska E., Marczewski W., Lebecka R., Flis B., Schäfer-Pregl R., Salamini F., Gebhardt C. 2000. QTL analysis of new sources of resistance to Erwinia carotovora ssp. atroseptica in potato done by AFLP, RLFP, and resistance-gene-like markers. Crop Sci. 40 (4): 1156-1167. 